\title{
Toxic Elements in Mountain Soils (Little Beskids, Polish Carpathians)
}

\author{
Andrzej Jaguś ${ }^{*}$, Mariusz Skrzypiec ${ }^{2}$ \\ 1 University of Bielsko-Biala, Willowa 2, 43-309 Bielsko-Biała, Poland \\ 2 Graduate of the University of Bielsko-Biala, Poland \\ *Corresponding author's e-mail: ajagus@ath.bielsko.pl
}

\begin{abstract}
The research consisted in the analyses pertaining to the occurrence of elements regarded as toxic $(\mathrm{Zn}, \mathrm{Cu}, \mathrm{Ni}, \mathrm{Cr}$, $\mathrm{As}, \mathrm{Pb}, \mathrm{Cd}, \mathrm{Hg}$ ), the presence of which in the environment is mainly associated with economic-industrial activities in mountain soils. The research area of about $5 \mathrm{sq} . \mathrm{km}$. included the hilltops and south-western slopes of the Magurka Wilkowicka massif. The massif is situated on the western edge of the Little Beskids near the area of BielskoBiała city. The concentrations of elements were measured in 50 soil samples taken from three zones: at the foothill of the massif (arable fields), on its slopes (forest areas) and on the hilltop (grassland). Additionally, the $\mathrm{pH}$ of the soil samples was determined. The research showed that zinc and, to a lesser degree, copper and nickel, occurred in the highest concentrations at the foot of the massif, near built-up areas, while the highest concentrations of arsenic and lead were detected in the hilltop part of the grassland. The concentrations of chromium, cadmium and mercury did not differ spatially. The analysed elements, especially zinc and lead, often occurred in the concentrations higher than those regarded as natural. It is a disturbing fact combined with serious acidity of the analysed soils (almost $60 \%$ of the samples were very acid soils), which may increase mobility of metals. The research shows that the soil environment of the Polish Carpathians may be contaminated with toxic elements not only in the neighbourhood of built-up areas, but also in the undeveloped land.
\end{abstract}

Keywords: toxic elements, mountain areas, soil contamination, soil acidity

\section{INTRODUCTION}

In the soil environment, toxic elements, which should mainly be associated with heavy metals, are usually absorbed by mineral (e.g. clay minerals, iron hydroxides) and organic (e.g. humus compounds) particles. They are, however, capable of various and reversible chemical reactions and their mobility depends on a number of factors, including the soil pH reaction (Dube et al. 2001). In the case of natural origin (geological preconditions), their concentrations are generally low and are not dangerous for living organisms. However, common anthropogenic impact (discharge of contaminants into the environment as a result of various economic, industrial and mining activities) often results in dangerously high concentrations of these substances in soils (Kabata-Pendias and Pendias 1999). The concentration monitoring is important for biological safety, as toxic elements have a negative impact on the biological activity of soils and other agrochemical parameters (Wyszkowska and Kucharski 2003) and may also penetrate plant tissues (Madejon et al. 2018).

The toxic element concentrations in Polish soils are spatially diversified (Siebielec et al. 2012). Therefore, it is necessary to estimate contamination at the local level. The aim of the research was to analyse the occurrence of toxic elements in mountain soils of southern Poland, that is in the Polish Carpathians. These areas are regarded as non-contaminated. The research allowed for verification of this claim. The research included four elements which are essential, in trace amounts, for plant growth, namely $\mathrm{Zn}, \mathrm{Cu}, \mathrm{Ni}, \mathrm{Cr}$, as well as 4 elements which have no physiological function, that is $\mathrm{As}, \mathrm{Pb}, \mathrm{Cd}, \mathrm{Hg}$ (Siebielec et al. 2012). 


\section{METHODS}

The research area for soil sample intake was selected in the Magurka Wilkowicka massif, situated on the western edge of the Little Beskid Mts within the city of Bielsko-Biała (Figure 1). The research covered an area of $5 \mathrm{sq} . \mathrm{km}$. The area included the foothills of the massif near the location of Wilkowice (about $450 \mathrm{~m}$ a.s.1.), its south-western slopes and the hilltops (about $900 \mathrm{~m}$ a.s.1.) (Figure 1). With the research area defined, it was possible to carry out the research within three main forms of use of the Polish Carpathians. These forms are arable land at the foothills of the mountains, forest areas on the slopes and grassland on the hilltops.

Fifty samples were collected within the research area for laboratory analyses pertaining to the concentrations of toxic elements. The samples were taken in the form of about $15-\mathrm{cm}-$ thick cores from the arable, sub-litter and sub-turf layers. Each sample was averaged (by mixing several partial samples). The samples numbered 1-17 came from arable land of the Wilkowice area, 18-33 - from forest areas and 34-50 - from used and fallow grassland of the hilltop of the massif zone (Figure 2).
The samples, 200-300 $\mathrm{g}$ in weight, were transported to the laboratory in cotton sacks and then dried at $40^{\circ} \mathrm{C}$, powdered and sifted through a $2-\mathrm{mm}$ mesh sieve. The $<2 \mathrm{~mm}$ fraction was analysed for elements, which is in accordance with the Polish normative notation (Rozporządzenie 2016).

In order to determine the concentrations of $\mathrm{Zn}, \mathrm{Cu}, \mathrm{Ni}, \mathrm{Cr}, \mathrm{As}, \mathrm{Pb}$ and $\mathrm{Cd}, 0.5 \mathrm{~g}$ of each sample was taken. The portion was treated with $12 \mathrm{~cm}^{3}$ of aqua regia in a Teflon tube. Moreover, a zero sample with certified reference material was prepared. The tube material was mineralized in a rotor of microwave mineralizer Mars from CEM company. Following mineralization, the contents of the tubes were moved to special plastic containers and filled with distilled water up to $50 \mathrm{~cm}^{3}$. The final marking was carried out using atomic emission spectrometry with a VARIAN spectrometer.

The Hg concentration was estimated using the LUMEX Ra-915+ atomic absorption spectrometer. In the case of soil samples, pyrolysis is first carried out in a special device (RP-91C attachment), which consists in a thermal release of mercury from the bond to the atomic state. The fumes with released mercury atoms undergo Zee-

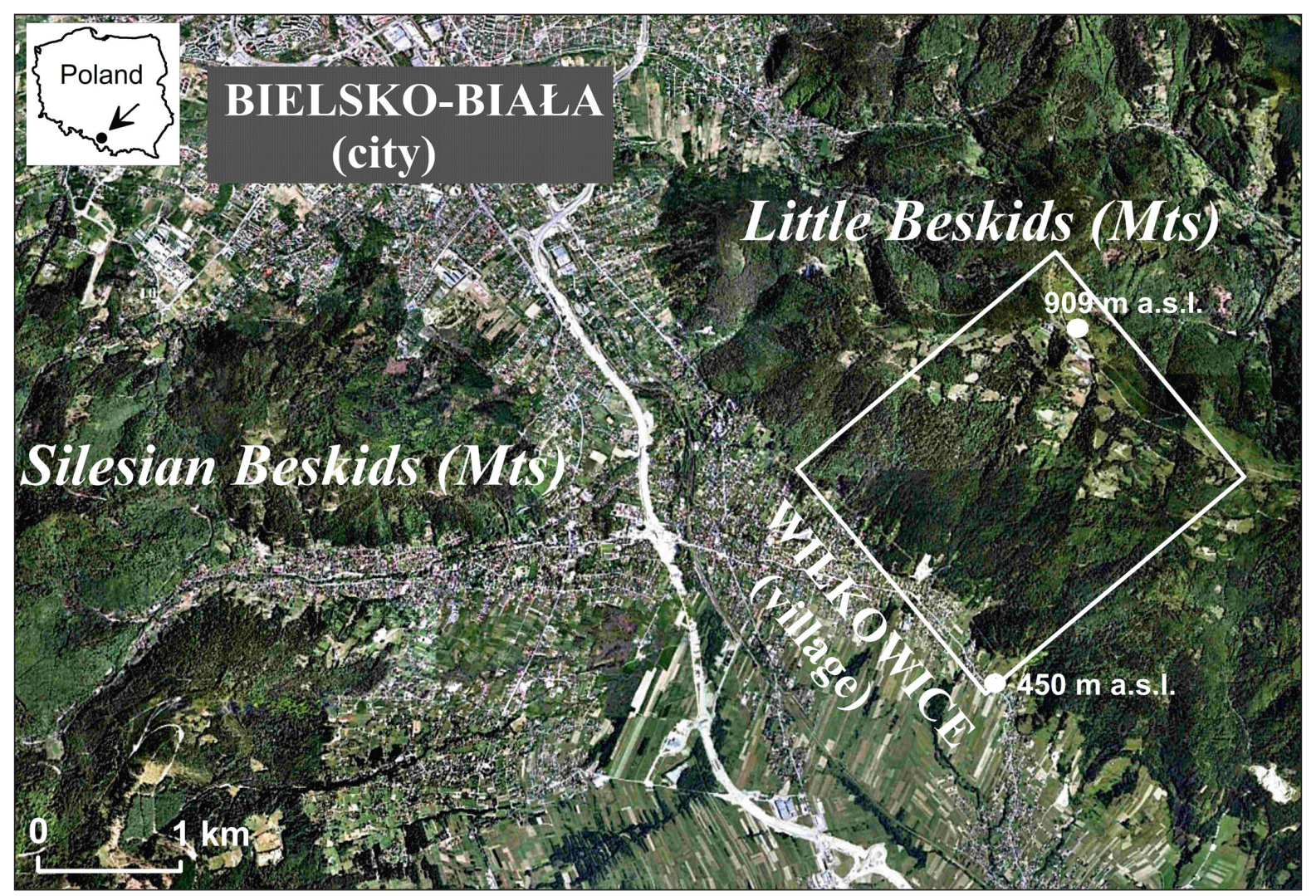

Figure 1. Location of the research area - marked as rectangle (based on Google Earth picture) 


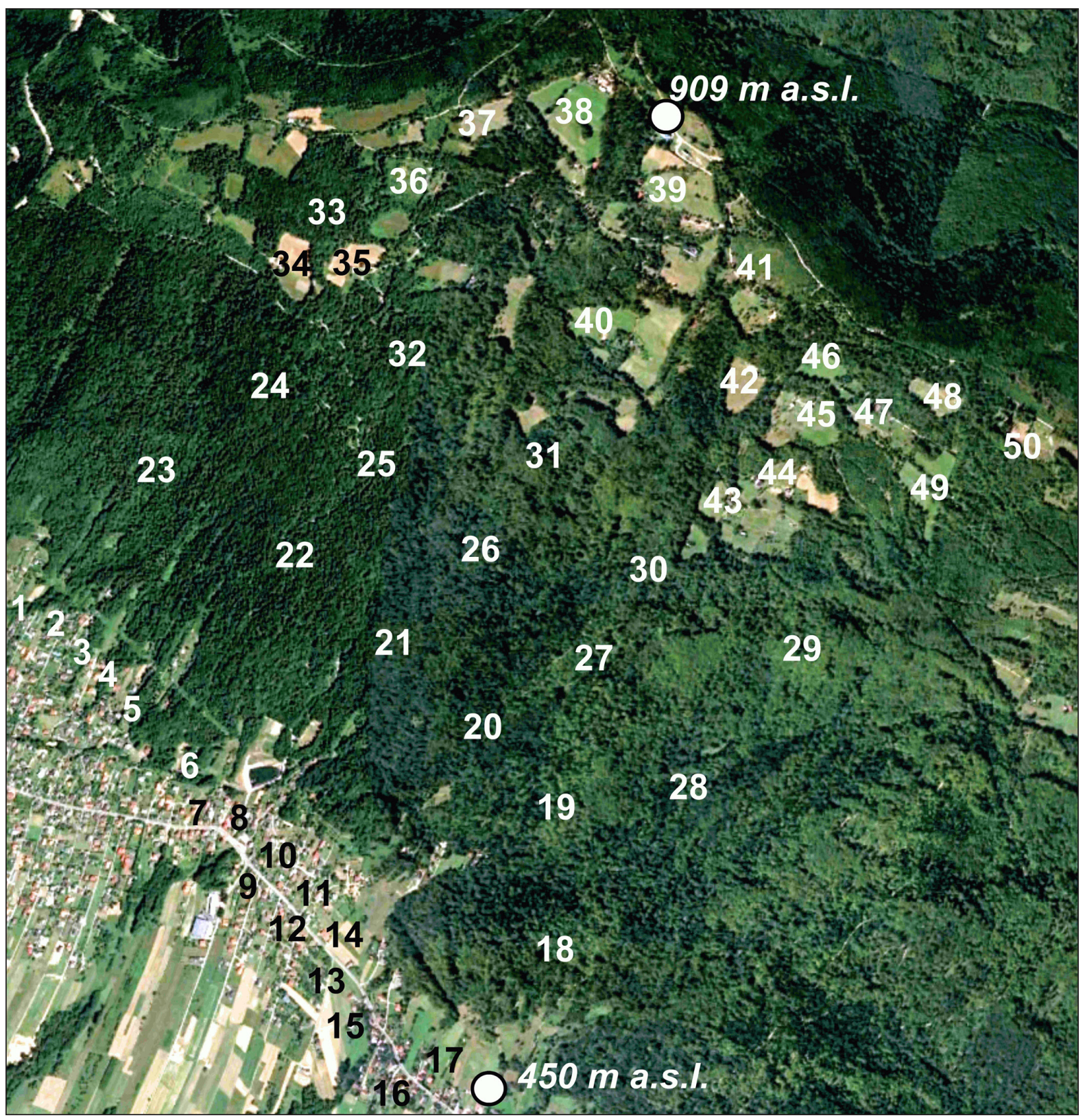

Figure 2. Location of the soil sampling places (based on Google Earth picture)

man spectroscopy in the basic device. According to the procedure, the zero sample with purified and roasted sea sand was analysed along with the soil samples.

The acidity of soil samples was estimated in distilled water using the electrometric method - a VWR pH-meter.

\section{RESULTS AND DISCUSSION}

\section{Use of the research field}

The analyses of soil-farming maps (provided by the Geodesy-Cartography Department of
Bielsko-Biała) show that acidic brown soils of loam grain size are the dominant soils in the research area. Loams are more silty at the foothill of the massif and more sandy on the hilltop. The soils with this grain size are regarded to be good in agrotechnical terms and have high nutritive potential.

Use of land within the research area, or in mountainous areas of southern Poland in general, currently consists in small-scale production for individual needs or market trade. Foothills are managed most intensively. Farmsteads usually have potato, mixed vegetable, rapeseed or grain (mainly triticale) fields. Some households keep farm animals, often as a tradition or by custom. 
Thus, the use of meadow or pasture fields near farms can also be observed. Animal fertilizers are used on arable land or, when there is a great amount of them, on meadows. Sadly, there is a lot of set-aside land, where vegetation which spreads includes mainly: Agropyron repens, Dactylis glomerata, Hypericum maculatum, Urtica dioica, Betula pendula, Alnus incana.

Mountain slopes are mostly covered by mixed forest, clearing waste land and set-aside at various stages of spontaneous afforestation, which are left of recent agricultural activities. Since this is a zone of the steepest slopes, it should remain forested due to necessary rainfall retention and prevention of erosion processes. However, measures should be taken to change the tree stand from mainly spruce to fir-beech (appropriate for habitat conditions) and eliminate uncontrolled auto-afforestation.

The hilltop parts feature grassy areas which are partly used as meadows and pastureland and partly abandoned. Traditional grazing of sheep and accompanying cattle is typical there - botanically, such conditions favour Lolio-Cynosuretum grazing communities and degraded HieracioNardetum of little value. Hay meadows situated near mountain settlements include the GladioloAgrostidetum communities. However, the setaside areas are spread with unfavourable vegetation successions - species of Carduus, as well as Nardus stricta, Vaccimium myrtillus, Rubus idae$u s$, and self-sown trees. Due to low agricultural usability of these grounds (shallow, rocky soils) and high absolute altitudes, this zone should be used as a source of cheap natural grass fodder.

\section{Occurrence of elements in soils}

The research showed that the concentrations of most elements in soils were spatially diversified to a smaller or greater extent. Only the concentrations of chromium, cadmium and mercury were measured at similar levels throughout the whole research area (Table 1).

Zinc (Zn) is a highly mobile element in the soil environment, although it is also sometimes accumulated in surface layers because of it creates quite durable bonds with organic matter (Ociepa et al. 2013). The average concentrations of zinc in various parts of the world range between 30 and 125 ppm (Kabata-Pendias and Pendias 1999). According to the criteria by Polish Institute of Soil Science and Plant Cultivation in Puławy, soils which include over $100 \mathrm{ppm}$ of zinc are regarded to be contaminated with this element (Siebielec et al. 2012).
In the research area, zinc occurred in $159.9 \mathrm{ppm}$ on average, with values over $100 \mathrm{ppm}$ concerning $40 \%$ of the samples, which were taken mainly from arable land within the village of Wilkowice. Hence, the highest concentrations were typical of land neighbouring the built-up areas. It probably results from the deposition of metal-bearing dust from low emissions, transport contamination and, possibly, chemicals used in agriculture.

Copper $(\mathrm{Cu})$ occurs in the concentrations up to $40 \mathrm{ppm}$ under natural conditions (Siebielec et al. 2012), while Polish norms (Rozporządzenie 2016) allow concentrations of the element at up to 100-300 ppm in agricultural land, depending on soil granulation, and up to $300 \mathrm{ppm}$ in forest areas. Within the research area, the copper concentrations were within $2.93-54.2 \mathrm{ppm}$ (18.3 ppm on average). The threshold of $40 \mathrm{ppm}$ was only exceeded in the case of 4 samples located at the foothill of the massif (arable land). The recorded concentrations, which generally reflect the natural conditions, are toxicologically safe. Under such conditions, assimilated copper has a positive effect on plant metabolism, by taking part in regulation of reproduction processes, photosynthesis and respiration (Zhang et al. 2011).

Nickel (Ni) was reported in soil samples in the concentrations between 7.4 and 30.9 ppm (15.1 ppm on average). Such concentrations reflected the natural ones (below $50 \mathrm{ppm}$ ) and acceptable levels for soils in the agricultural and forest areas (Siebielec et al. 2012, Rozporządzenie 2016). Slightly higher concentrations were related to land within the village of Wilkowice. This suggests an impact of the built-up areas on the increased contents of $\mathrm{Ni}$ in the environment.

Chromium (Cr) occurred in between 13.4 and $44.9 \mathrm{ppm}$, which does not suggest contamination of soils with this element, as contamination levels are set at several hundred ppm (Rozporządzenie 2016). No spatial diversification of concentra-

Table 1. Mean concentrations [ppm] of toxic elements in soils in the Magurka Wilkowicka massif

\begin{tabular}{|c|c|c|c|}
\hline Element & $\begin{array}{c}\text { Arable land } \\
\text { soils }\end{array}$ & $\begin{array}{c}\text { Forest land } \\
\text { soils }\end{array}$ & $\begin{array}{c}\text { Grassland } \\
\text { soils }\end{array}$ \\
\hline $\mathrm{Zn}$ & 201.8 & 119.2 & 99.1 \\
\hline $\mathrm{Cu}$ & 23.4 & 16.7 & 15.3 \\
\hline $\mathrm{Ni}$ & 16.5 & 14.5 & 12.6 \\
\hline $\mathrm{Cr}$ & 22.1 & 24.3 & 24.0 \\
\hline $\mathrm{As}$ & 9.2 & 13.8 & 18.7 \\
\hline $\mathrm{Pb}$ & 71.9 & 103.4 & 145.5 \\
\hline $\mathrm{Cd}$ & 1.2 & 1.3 & 1.2 \\
\hline $\mathrm{Hg}$ & 0.2 & 0.2 & 0.2 \\
\hline
\end{tabular}


tions was reported - they were at an average level of slightly over $20 \mathrm{ppm}$ in each of the research zones (foothills, slopes and hilltop of the massif). In spite of low concentrations, the occurrence of chromium should not be ignored as it has toxic properties depending on many agrochemical factors, especially the status of nutrient element (Nguyen et al. 2017).

Arsenic (As) was reported in the concentrations up to $38.7 \mathrm{ppm}$ (3.7 ppm on average), with three samples where it was not detected (below 5 $\mathrm{ppm}$ ). Its average contents in soils of different parts of the world are estimated at 0.2-16.0 ppm (Kabata-Pendias and Pendias 1999), while the allowed concentration in Poland is $50 \mathrm{ppm}$ in forest areas and $10-50 \mathrm{ppm}$ in arable land, depending on soil granulation (Rozporządzenie 2016). The threshold concentration in the research area was $20 \mathrm{ppm}$. This limit was exceeded in seven samples taken from the grassland. Thus, unexpectedly, excessive concentrations occurred in the hilltop zone of the massif rather than in the Wilkowice region. This zone is occupied by grassland, which makes the area exposed to atmospheric deposition, contrary to forest ecosystems. It seems that high concentrations of arsenic in the soils of the hilltop may result from this transregional atmospheric deposition (e.g. from the neighbouring Upper Silesian and Ostrava industrial regions). The research proves that the metals from industrial emission may be transferred through the atmosphere even to remote areas (Kyllönen et al. 2009).

Lead $(\mathrm{Pb})$, like arsenic, occurred in its highest concentrations in the hilltop soils (grassland). The average reported in that zone was $145.5 \mathrm{ppm}$ of lead, while the average for the whole research area was $105 \mathrm{ppm}$. These concentrations should be regarded as high, as the natural concentration is assumed to be at up to $70 \mathrm{ppm}$ (Siebielec et al. 2012). This level was exceeded in $64 \%$ of samples. In two of the samples, lead occurred in very high amounts (260 and $346 \mathrm{ppm}$ ), which exceeded the contamination norms for grassland $-250 \mathrm{ppm}$ (Rozporządzenie 2016). The element migrates poorly in the soil environment and is usually concentrated in layers related to the bedrock under natural conditions. The concentrations reported in the surface soil layers suggest the anthropogenic impact, most probably through the atmosphere. As lead is concentrated in roots of plants (Kabata-Pendias and Pendias 1999), the toxicological threat concerns mainly root vegetables and, consequently, vegetable fields at the foothills, where natural levels happened to be exceeded.
Cadmium (Cd) occurs in less than $1 \mathrm{ppm}$ in non-contaminated soils (Siebielec et al. 2012), whereas this value was reported to be exceeded in $22 \%$ of samples. It is very unfavourable because of easy absorption of $\mathrm{Cd}$ from soil by vegetation and accumulation of the element in tissues at each trophic level (Zhang et al. 2011). The maximum reported levels were at $6.71 \mathrm{ppm}$; on the other hand, the element was not detected in $36 \%$ of the samples (concentrations below the detection threshold $-0.25 \mathrm{ppm})$. In terms of the legal standards (Rozporządzenie 2016), soils of the research area were contaminated with cadmium in two cases (1 sample in arable land and one in grassland). The cadmium concentrations did not differ spatially.

Mercury $(\mathrm{Hg})$ is a particularly toxic element, accumulating in soils (especially in organic matter) and living organisms (Carrasco et al. 2013). Its accepted concentration in the soils of the research field is $4 \mathrm{ppm}$ in agricultural land and $10 \mathrm{ppm}$ in forest areas (Rozporządzenie 2016), but the range $0.05-0.3 \mathrm{ppm}$ is regarded as a natural concentration (Kabata-Pendias and Pendias 1999). Between 0.04 and $0.85 \mathrm{ppm}$ of this metal was reported in the analysed samples (the average was $0.19 \mathrm{ppm}$ ). No regularities were found in the spatial distribution of the concentrations - they were similar throughout the research area.

\section{Soil reaction}

The research also included the soil $\mathrm{pH}$, as the forms of occurrence and, consequently, mobility of toxic element in the soil environment are highly dependent on this particular parameter (Jing et al. 2018). Specific $\mathrm{pH}$ may favour accumulation of the element, its assimilation by vegetation or its migration outside the soil profile. Generally, increased acidity results in elevated mobility of many metals and intensity of their absorption by vegetation.

The researched soils turned out to be acidified, which, in the case of agricultural land, results from the malpractices in natural fertilization and liming. The measured $\mathrm{pH}$ did not exceed 5.0, which is very acidic reaction, in 58\% samples. Only six samples (out of fifty) had a neutral $\mathrm{pH}$ ( $\mathrm{pH}$ 6.8-7.4), and two were alkaline $(\mathrm{pH} \geq 7.5)$. Low $\mathrm{pH}$ concerned mainly the soils of the hilltop areas and forest soils. In the hilltop zone, $\mathrm{pH}$ ranged between 3.7 and 6.9 , with an average at 4.4. In the zone of forested slopes, $\mathrm{pH}$ was reported at 3.7-7.2, with an average at 4.9. In the zone of the foothill of the massif (arable land), the $\mathrm{pH}$ was at 5.8 on average, and its values ranged between 4.0 and 8.8. A favourable $\mathrm{pH}$ was only 
reported locally, and as expected, it was related to the managed arable land of the Wilkowice area.

The obtained results and agrotechnical instruction materials show that the research area would need liming for the agricultural use to grow. The current $\mathrm{pH}$ may result in decreased absorption of important nutritive elements by vegetation, deterioration of the root system by $\mathrm{Al}^{3+}$ ions, or infiltration of toxic elements to plant tissues (Rahmonov et al. 2011, Rzetala et al. 2011, Wang et al. 2013).

\section{CONCLUSION}

1. The soils of mountain regions of southern Poland may be contaminated with toxic elements, which was proven by the research in the area of the Magurka Wilkowicka massif (the Little Beskid Mts).

2. Contamination occurs both at the foothills, near built-up areas (especially zinc), and in the hilltop zone far from the emission sources (especially arsenic and lead).

3. The occurrence of $\mathrm{Zn}, \mathrm{As}, \mathrm{Pb}, \mathrm{Cd}$ in the concentrations regarded as above natural may be a toxicological threat, especially if the element is not necessary for physiological processes of living organisms.

4. Soils of mountain areas are generally highly acidified, which should be regarded as a threat of infiltration of toxic elements into the food chain.

\section{REFERENCES}

1. Dube A., Zbytniewski R., Kowalkowski T., Cukrowska E., Buszewski B. 2001. Adsorption and migration of heavy metals in soil. Polish Journal of Environmental Studies, 10(1), 1-10.

2. Carrasco-Gil S., Siebner H., LeDuc D.L., Webb S.M., Millán R., Andrews J.C., Hernández L.E. 2013. Mercury localization and speciation in plants grown hydroponically or in a natural environment. Environmental Science and Technology, 47(7), 3082-3090.

3. Jing F., Chen X.M., Yang Z.J., Guo B.L. 2018. Heavy metals status, transport mechanisms, sources, and factors affecting their mobility in Chinese agricultural soils. Environmental Earth Sciences, 77(3), article number 104.

4. Kabata-Pendias A., Pendias H. 1999. Biogeochemia pierwiastków śladowych. PWN, Warszawa.
5. Kyllönen K., Karlsson V., Ruoho-Airola T. 2009. Trace element deposition and trends during a ten year period in Finland. Science of the Total Environment, 407, 2260-2269.

6. Madejon P., Dominguez M.T., Madejon E., Cabrera F., Maranon T., Murillo J.M. 2018. Soil-plant relationships and contamination by trace elements: A review of twenty years of experimentation and monitoring after the Aznalcollar (SW Spain) mine accident. Science of the Total Environment, 625, 50-63.

7. Nguyen K.L., Nguyen H.A., Richter O., Pham M.T., Nguyen V.P. 2017. Ecophysiological responses of young mangrove species Rhizophora apiculata (Blume) to different chromium contaminated environments. Science of the Total Environment, 574, 369-380.

8. Ociepa E., Ociepa-Kubicka A., Okoniewska E., Lach J. 2013. Immobilizacja cynku i kadmu w glebach w wyniku stosowania substratów odpadowych. Rocznik Ochrona Środowiska, 15, 1772-1786.

9. Rahmonov O., Rzetala M.A., Rahmonov M., Kozyreva E., Jagus A., Rzetala M. 2011: The formation of soil chemistry and the development of fertility islands under plant canopies in sandy areas. Research Journal of Chemistry and Environment, 15(2), 823-829.

10. Rozporządzenie Ministra Środowiska z dnia 1 września 2016 r. w sprawie sposobu prowadzenia oceny zanieczyszczenia powierzchni ziemi. Dz.U. 2016, poz. 1395.

11. Rzetala M.A., Rahmonov O., Jagus A., Rahmonov M., Rzetala M., Machowski R. 2011: Occurrence of chemical elements in common reeds (Phragmites australis) as indicator of environmental conditions. Research Journal of Chemistry and Environment, 15(2), 610-616.

12. Siebielec G., Smreczak B., Klimkowicz-Pawlas A., Maliszewska-Kordybach B., Terelak H., Koza P., Hryńczuk B., Łysiak M., Miturski T., Gałązka R., Suszek B. 2012. Monitoring chemizmu gleb ornych w Polsce w latach 2010-2012 (raport końcowy). Instytut Uprawy Nawożenia i Gleboznawstwa PIB, Puławy.

13. Wang X.M., Zhou C.C., Liu G.J., Dong Z.B. 2013. Transfer of metals from soil to crops in an area near a coal gangue pile in the Guqiao Coal Mine, China. Analytical Letters, 46(12), 1962-1977.

14. Wyszkowska J., Kucharski J. 2003. Właściwości biochemiczne i fizykochemiczne gleby zanieczyszczonej metalami ciężkimi. Zeszyty Problemowe Postępów Nauk Rolniczych, 492, 435-442.

15. Zhang H.Z., Li H., Wang Z., Zhou L.D. 2011. Accumulation characteristics of copper and cadmium in greenhouse vegetable soils in Tongzhou District of Beijing. Procedia Environmental Sciences, 10, 289-294. 